\title{
Technological Prospection with a Focus on Assistive Technology in Adapted Vehicles for People with Disabilities
}

\author{
Rosemeire do Carmo Furtado ${ }^{1 *}$, Camila Pereira Guizzo ${ }^{1}$, Xisto Lucas Travassos ${ }^{2}$ \\ ${ }^{I}$ GETEC, Senai Cimatec University Center; Salvador, Bahia; ${ }^{2}$ Technological Center, Federal University of Santa Catarina; \\ Joinville, Santa Catarina, Brazil
}

\begin{abstract}
This study aimed to review the production of patent documents related to assistive technology on adapted vehicles for people with disabilities. The technological prospection was carried out through a search on the Espacenet database, resulting in 277 patents whose data we organized into charts. The results show that the total number of patents filed in this area is small and with a limited increase over the years, maybe due to industrial secrecy. Twenty-eight countries registered patents. The Republic of China and the Korea Republic were the main depositors, while Brazil registered only one patent. They focused on people with a physical disability, so further projects to attend to other types of disability are also required. There is a necessity to increase government and private sectors investments for technological advances in this area.
\end{abstract}

Keywords: Assistive Technology. People with a Disability. Vehicles. Patents.

\section{Introduction}

According to the Brazilian Law on the Inclusion of Persons with Disabilities (LBI - Lei Brasileira de Inclusão, in Portuguese) [1], a person with a disability is that one that has a long-term impairment of a physical, mental, intellectual, or sensory nature. And their interaction with one or more barriers may hinder their full and effective participation in society on equal terms with other people. As stated by World Health Organization (WHO) [2], about $15 \%$ of the world population or an estimated 1 billion people live with disabilities. Brazil has almost 46 million people with disabilities (PwD), which corresponds to $24 \%$ of its total population.

Most of them present visual or physical impairment and is more than 60 years old [3]. Between 2000 and 2015, the life expectancy increased by 5 years globally and Brasil registered a life expectancy of 75 years, and the tendency was to increase it even more [4]. There was a

Received on 15 September 2021; revised 29 October 2021. Address for correspondence: Rosemeire do Carmo Furtado. Avenida Orlando Gomes, 1845, Piatã, Zip Code: 41650-010, Salvador, BA, Brazil. Phone: +55 71 3879-5677. E-mail: rofurtad@yahoo.com.br.

J Bioeng. Tech. Appl. Health 2021;4(4):157-163.

(C) 2021 by SENAI CIMATEC. All rights reserved. decline of 1.94 years in 2020 due to the COVID-19 pandemic; this index in 2021 might drop even more [5]. Anyway, the world population tends to increase around $26 \%$, achieving 9,7 billion people in 2050 [6]. Of course, PwD quantity will proportionally increase with this.

Many PwD needs are not supported due to lack of infrastructure or investments and Brazil has been slow in addressing these issues compared with more developed countries. An arsenal of equipment, services, and specific strategies called assistive technology (AT) have been developed to minimize or eliminate the functional problems encountered by PwD. Per Portaria interministerial $\mathrm{n}^{\circ} 362$ [7], there are 12 AT categories:

1. Aid for daily life and practical life.

2. Augmentative and/or Alternative Communication.

3. Computer accessibility features.

4. Environmental control systems.

5. Architectural projects for accessibility.

6. Orthoses and prostheses.

7. Postural adequacy.

8. Mobility aids.

9. Aid for the qualification of visual ability and resources that expand information to people with low vision or blindness.

10. Aid for hearing ability and autonomy in communication to people with hearing loss, deafness, and deaf-blindness. 
11.Adaptations in vehicles and vehicle access environments.

12. Sports and leisure.

Overall, this study aims to characterize the current technological maturity in the subject related to assistive technology in adapted vehicles for people with disabilities, analyzing the progress of patent documents through a search on the Espacenet database. Technological prospection is useful to present the state-of-the-art of some technology area, obtain information about its past trajectory, and to market trends and perception of items to be improved [8].

\section{Materials and Methods}

We used the free-of-charge patent searching tool called Espacenet, from the European Patent Office (EPO), with more than 90 million patent documents from around the world. According to INPI (Instituto Nacional da Propriedade Industrial, in Portuguese) [9], the patent classification offers an effective search tool for patent documents by intellectual property offices and other users, intending to establish novelty and to evaluate the inventive step of technical disclosures in patent applications.

To understand the state-of-the-art assistive technology in adapted vehicles for people with disabilities, we searched a patent with a strategy that combined a set of keywords and International
Patent Classification (IPC) codes. The IPC, established by the Strasbourg Agreement 1971, provides for a hierarchical system of languageindependent symbols for the classification of patents and utility models according to the different areas of technology [10]. The keywords and/or IPC codes presented in table 1 were inserted on the field "title or abstract", returning 383 patent documents (Table 1).

We found the IPC codes on the International Patent Classification WIPO (World Intellectual Property Organization), which provides the contents of 70 million patents worldwide [10]:

- A61G 3/00 - Ambulance aspects of vehicles; Vehicles with special provisions for transporting patients or disabled people, or their conveyances.

- A61G 3/02 - Loading or unloading personal transports; Facilitating access of patients or disabled persons to get into, or exit from, vehicles.

- A61G 3/04 - Transfer of seated patients or disabled persons by swinging about an upright axis.

- A61G 3/06 - Transfer using ramps, lifts, or similar equipment.

- A61G 3/08 - Accommodating or securing wheelchairs.

By reading the 383 patent abstracts, only those patents focusing on PwD and adaptations in vehicles/vehicle access environments (AT number

Table 1. Keywords and IPC codes used for patent search on the European Espacenet database.

\begin{tabular}{lc}
\hline Keywords and/or IPC & $\begin{array}{c}\text { Number of } \\
\text { Patent Documents }\end{array}$ \\
\hline Disable and Vehicle and A61G3 & 280 \\
Disabled and A61G3/00 & 60 \\
Assistive Technolog and Vehicle & 22 \\
People with Disabilities and Vehicle & 8 \\
Disabled Person and Automotive & 7 \\
Disabled People and Automotive & 6 \\
Total & $\mathbf{3 8 3}$ \\
\hline
\end{tabular}


11) were selected, totaling 277 patents, which are the focus of this technological prospection study. The 277 patents were exported to CSVed 1.4.9 program and then to MicrosoftExcel for distribution of patent documents by the country of origin; annual progress of patent development; patent filings by principal applicants and inventors; distribution of patent documents by the main IPC codes.

\section{Results and Discussion}

\section{Origin of Patent Documents}

Figure 1 shows the distribution of patent documents by country. In total, 28 countries registered patents, being most of them belonging to China (48), followed by the Korea Republic
(40) and Japan (32). Even having a high number of PwD, Brazil has registered just one patent document. It reinforces the importance of fostering new AT projects for vehicles in this country.

\section{$\underline{\text { Annual Progress of Patent Documents }}$}

Figure 2 shows the global annual progress of patent publications between 1970 and 2020, illustrating that the number of patents filed in this study area is small (277) for 50 years. The first patent was filed in 1973 in the United States. However, there was an increased number of patent deposits between 2007 and 2014 with a peak of 19 patents in 2014 . Then there was a fall between 2015 and 2020, with a maximum number of 12 patents in 2018 and only 5 in 2020 . We can also notice many years with no patents in the studied

Figure 1. Distribution of patent documents by the countries with the highest number of deposited patent documents.

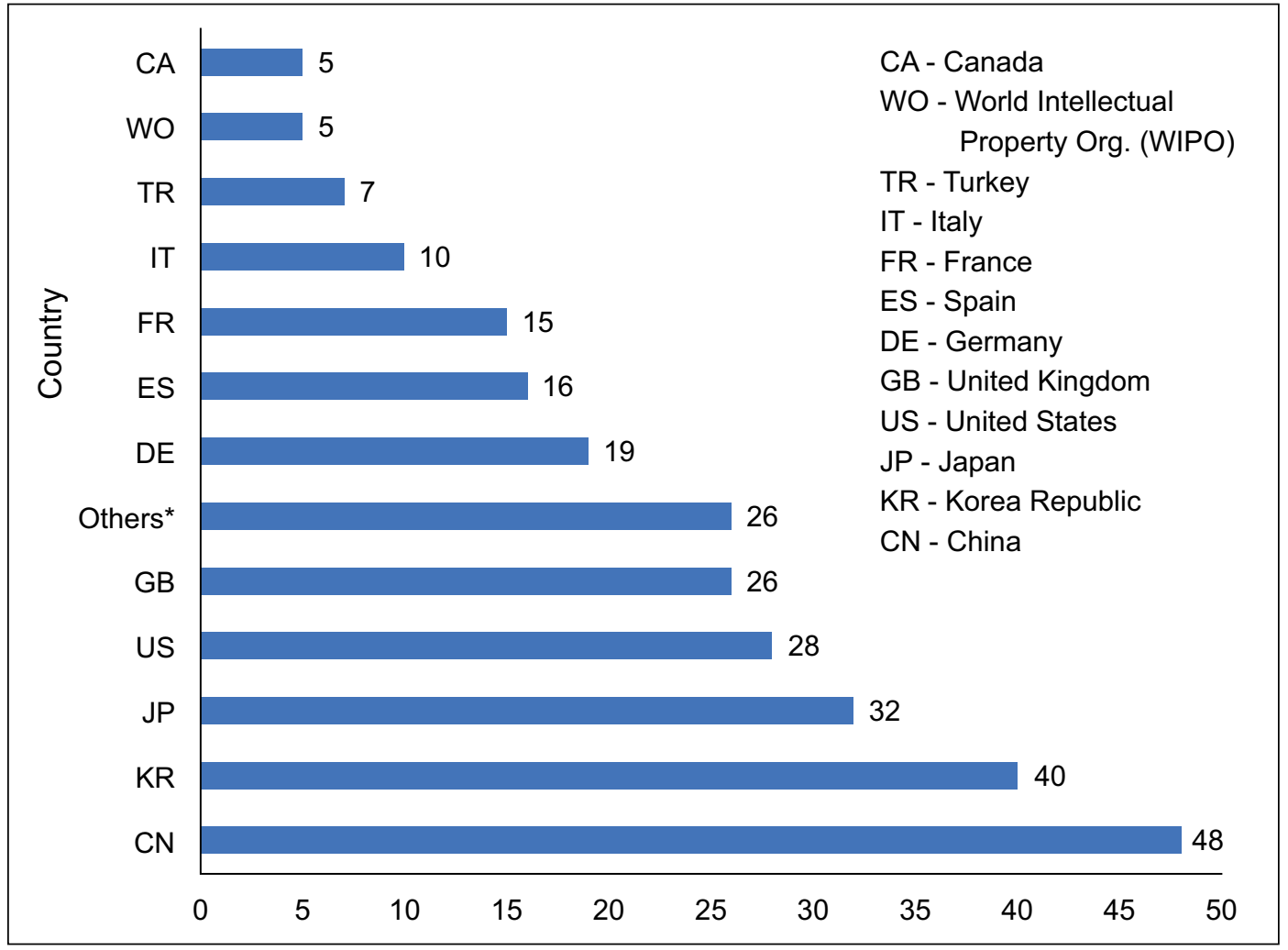

Others*: NZ - New Zealand, PL - Poland, AU - Australia, NL - Netherlands, HU - Hungary, FI - Finland, RU - Russia, AT - Austria, BR - Brazil, TW - Taiwan, SE - Sweden, SI -Slovenia, PT Portugal, CZ - Czech Republic, EP - European Patent Office (OPE/EPO), MX - Mexico. It appeared three times or less. 
area, and the increase of patents publications over the years is low.

\section{Principal Applicants (Depositors) of Patent Documents}

Regarding the holders of technology, the total number of patent documents spreads by different depositors. Auto Tech Corp company from the Korea Republic held the most with 8 patents, followed by Daguang $\mathrm{HU}$ from China with 6 patents and Toyota Auto Body CO LTD from Japan / Egan Thomas F from the United States with 4 patents each. In Figure 3, we can see the applicants with 3 or more deposited patents. The other 267 depositors appeared just once or twice. As expected, based on the previous analysis from, Brazil is not on the list of principal applicants.

\section{Main Inventors of Patent Documents}

Figure 4 shows the number of patent documents distributed by the inventor, and it considers only the ones with 3 or more deposited patents. The predominance of the Korea Republic appears again (21 patents), followed by the United States (9 patents) and China (6 patents). The other 413 investors appeared only once or twice. Kang Seong Hee (Korea), Egan Thomas F (United States), and Daguang $\mathrm{Hu}$ (China) have the highest number of patent documents, being 6 for each of them.

\section{International Patent Classification (IPC)}

The number of patent documents by IPC code is shown in Figure 5, containing only the principal ones that appeared 10 times or more. A61G3/06 is predominant (160 times), followed by $\mathrm{A} 61 \mathrm{G} 3 / 00$ (83 times), $\mathrm{A} 61 \mathrm{G} 3 / 02$ (76 times), and AG61/08 (43 times). Other 176 codes not available in the chart were cited 8 times or less. The A61G3 code family (ambulance aspects of vehicles; vehicles with special provisions for transporting patients or disabled persons, or their conveyances) is predominant with $39 \%$ of total IPC codes that appeared on this search. From this, the highest portion (44\%) is related to projects for transferring using ramps, lifts, or similar equipment (A61G3/06). Therefore, most of the projects are focused on AT related to vehicle access environments.

\section{Conclusion}

This study demonstrates that, despite the relevance of this subject, there is still not a representative number of patents related to AT in adapted vehicles for PwD. According to the presented data, there is a dominance from China, Korea Republic, Japan, and United States on the assistive technology in adapted vehicles for people with disabilities. It is probably driven by incentives led by their governments for Research and Development (R\&D) in the fields related to technology. Even having a high quantity of PwD, Brazil has only one deposited patent. All the patent documents analyzed in this technological prospection refer to mobility and accessibility assistance, focused on people with a physical disability. So, further projects to attend to other types of disability are also required. There are opportunities and needs for increasing investments in AT projects inside the vehicles, mainly to support PwD to drive them. The increase of patents deposits over the years is low and it may be related to companies' confidentiality policies that limit their publications. In the automotive industry, many innovations are protected by patents but there is a lot of restriction on data disclosure due to industrial secrecy. Furthermore, the time and scope of research work are not reflected in innovations incorporated by business models. Another issue is that the TA projects are expensive and do not always provide the financial return desired by the companies, limiting their investments. The global demand from the PwD and the needs for new assistive technology will continue growing in proportion to the increase and aging of the population.So,there is a necessity to increase 
Figure 2. Global growth of patent documents (annual progress between 1970 and 2020).

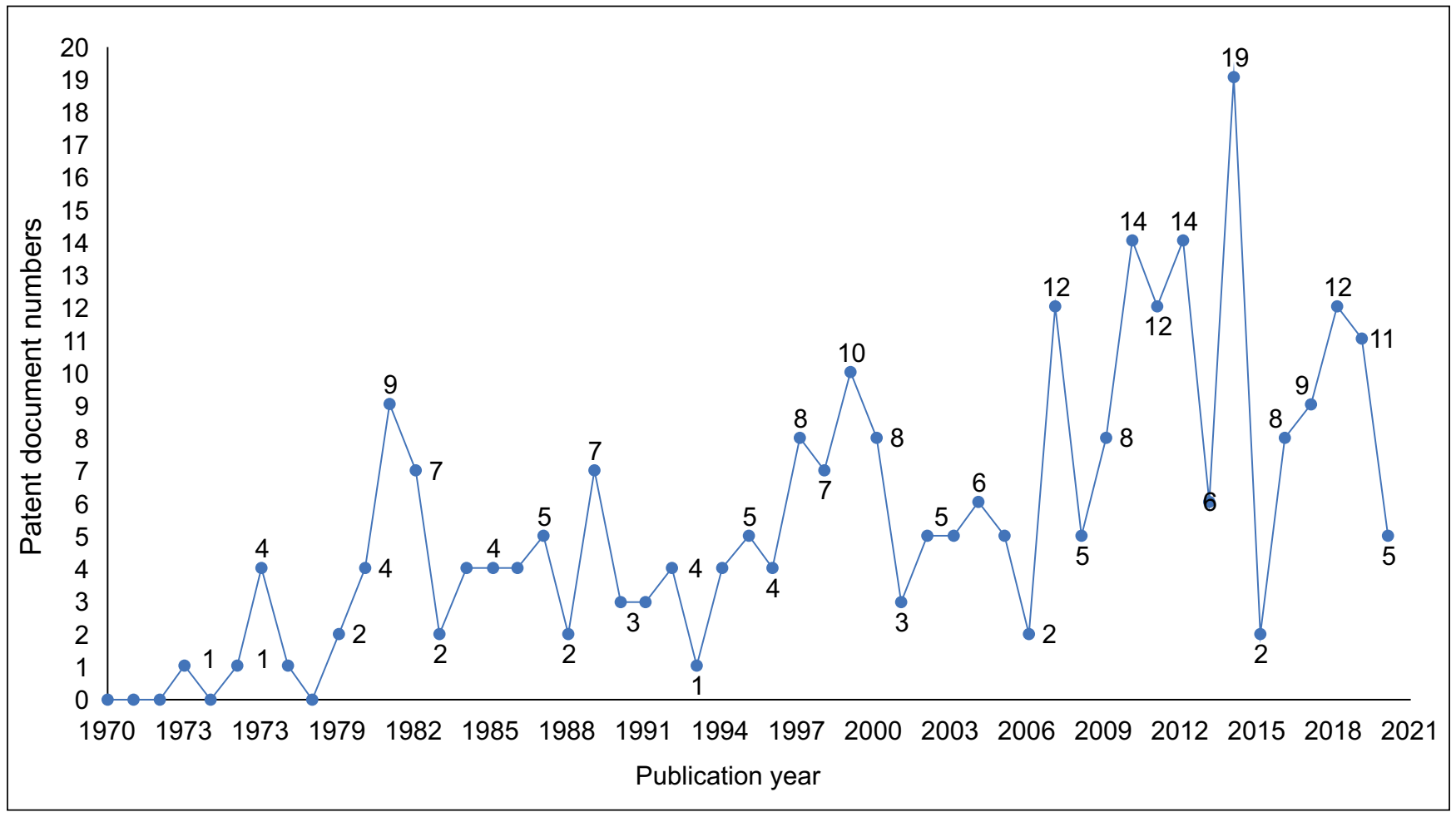

Figure 3. Principal applicants (depositors) of patent documents.

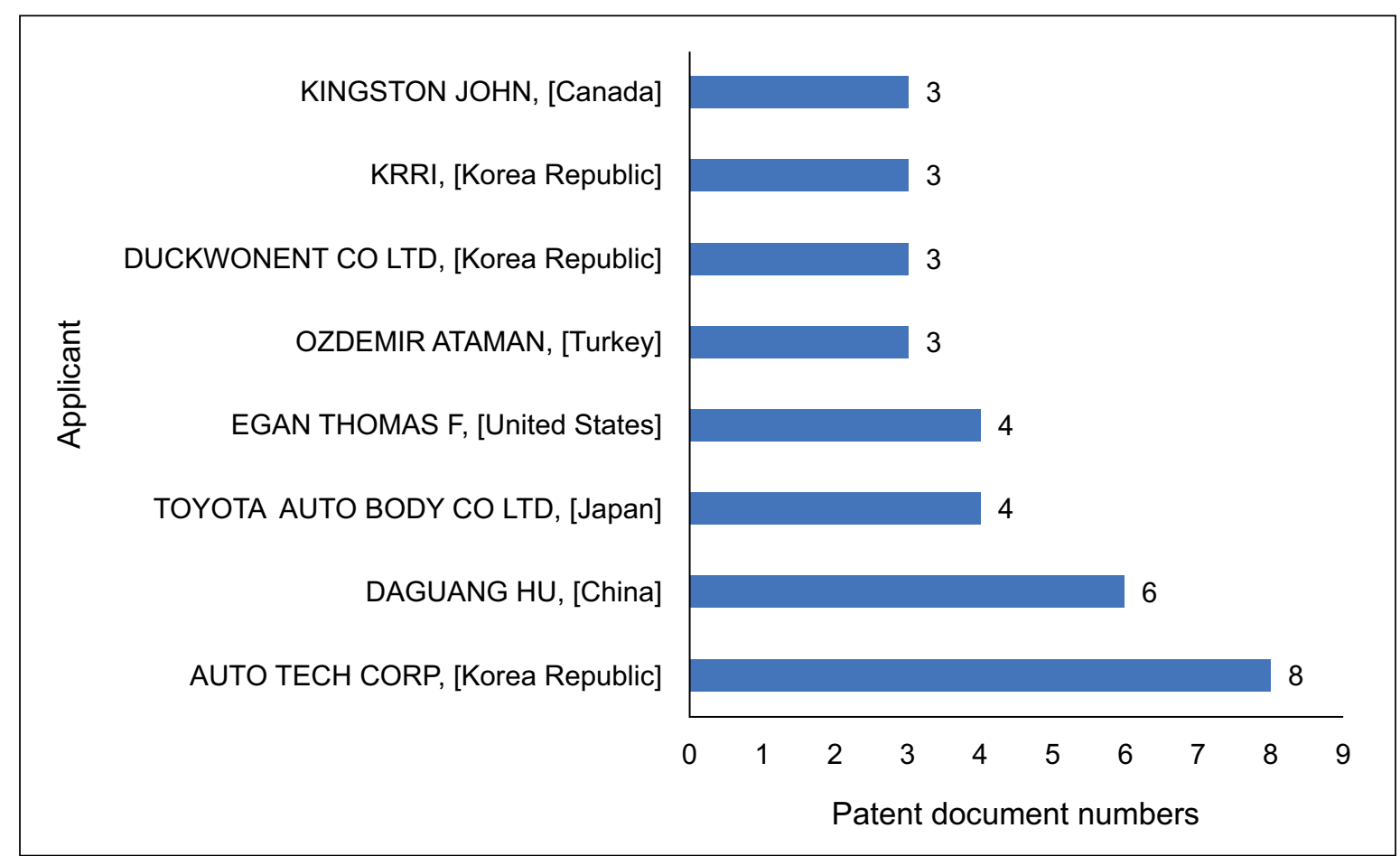


Figure 4. Principal inventors of patent documents.

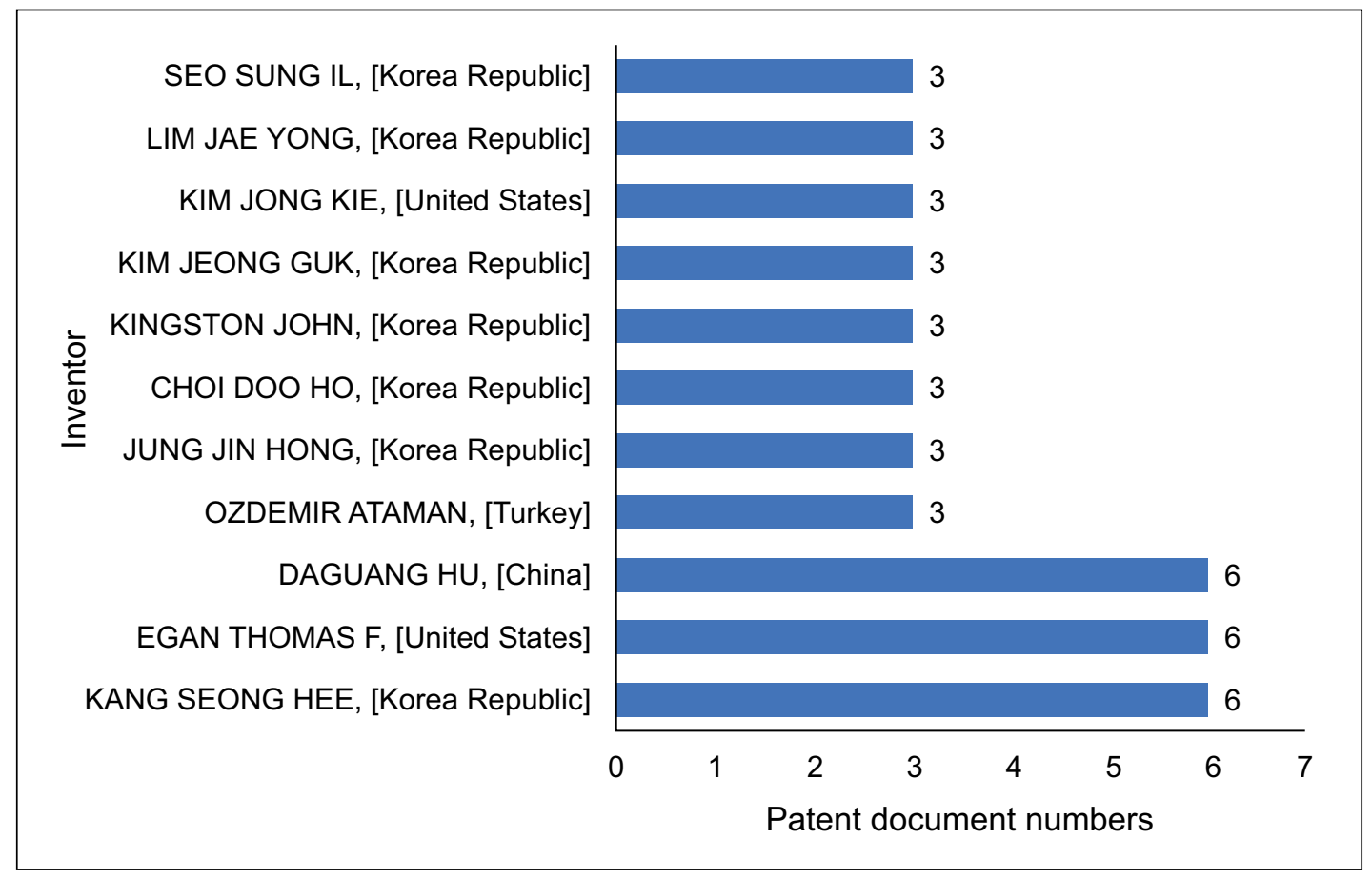

Figure 5. Distribution of patent documents by the principal International Patent Classification (IPC) code - with 10 deposited patents or more.

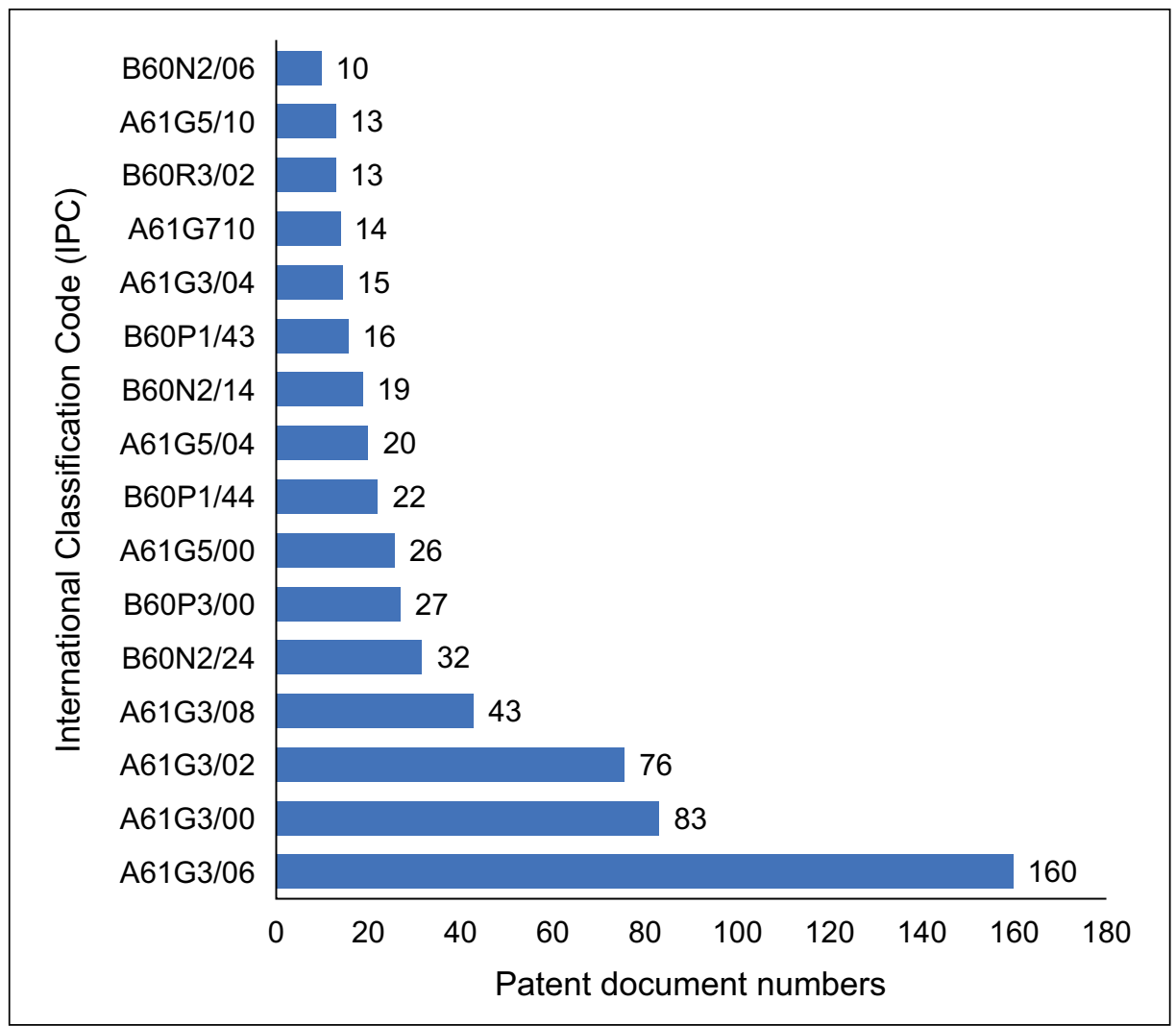


government and private sector incentives and investments for technological advances in this area; especially in Brazil with such an inexpressive patent actuation,

\section{References}

1. Brasil. Presidência da República Secretaria-Geral. Lei $\mathrm{n}^{\circ}$ 13.146, de 6 de Julho de 2015. Lei Brasileira de Inclusão da Pessoa com Deficiência (Estatuto da Pessoa com Deficiência). Available at: <http://www. planalto.gov.br/ccivil_03/_ato2015-2018/2015/lei/ 113146.htm>. Accessed on: 14 Mar. 2021.

2. WHO. World Health Organization. World Report on Disability, 2011. Available at: <https:/www.who.int/ publications/i/item/9789241564182>. Accessed on: 1 May 2021.

3. IBGE. Instituto Brasileiro de Geografia e Estatística, Censo 2010. Available at: < https://censo2010.ibge.gov. br/resultados.html $>$. Accessed on: 7 Jan. 2021.

4. OPAS. Organização Pan-Americana de Saúde, 2016. Available at: <https://www.paho.org/bra/index.p? option $=$ com_content $\&$ view $=$ article $\&$ id $=5102$ :omsexpectativa-de-vida-subiu-5-anos-desde-2000-mas- desigualdades-na-saudepersistem \&Itemid $=839>$. Accessed on: 10 Jan. 2021.

5. Castro MC, et al. Reduction in the 2020 life expectancy in Brazil after COVID-19. medRxiv, 2021.

6. UNDP. United Nations Development Programme. Human Development Report, 2019. Available at: $<$ http:/hdr.undp.org/sites/default/files/hdr2019.pdf $>$. Accessed on: 18 May 2021.

7. Brasil. Secretaria Especial de Fazenda. Portaria Interministerial $n^{\circ} 362$, de 24 de Outubro de 2012. Available at: <https://www.gov.br/fazenda/pt-br/ acesso-ainformacao/institucional/legislacao/portariasinterministeriais/2012/portaria-362>. Accessed on: 14 Mar. 2021.

8. Coelho GM, Coelho DMS.Prospecção tecnológica: metodologias e experiências nacionais e internacionais. Rio de Janeiro: INT, 2003.

9. INPI. Instituto Nacional da Propriedade Industrial. Classificação de patentes, 2020. Available at: $<$ https:// www.gov.br/inpi/pt-br/servicos/patentes/classificacaodepatentes $>$. Accessed on: 20 Feb. 2021.

10. WIPO. World Intellectual Property Organization. International Patent Classification (IPC), 2021. Available at: < https://www.wipo.int/classifications/ipc/ en/>. Accessed on: 15 Jan. 2020. 